\title{
Synthesis and Characterization of New Compounds Derived from Pyrrolidine-2-One and Evaluation of their Biological Activities
}

\author{
Nadia A. Betti ${ }^{*}, 1$, Redha Ib. Hussain², Sahar Ab. Kadhem² and Abdul Jabar Kh. Atia ${ }^{2}$ \\ ${ }^{1}$ Materials Engineering Department, University of Technology, Baghdad, Iraq \\ ${ }^{2}$ Department of Chemistry, College of Science, Mustansiriyah University, Baghdad, Iraq
}

\begin{tabular}{ll}
\hline \multicolumn{1}{c}{ Articles Information } & \multicolumn{1}{c}{ Abstract } \\
\hline $\begin{array}{l}\text { Received: } \\
11.10 .2019\end{array}$ & New derivatives of pyrrolidine-2-one have been prepared by lactamization of \\
Accepted: & $\gamma$-butyrolactone GBL with hydrazine hydrate ( $\mathrm{NH}_{2} \mathrm{NH}_{2}$ (80\%)) to afford \\
22.10 .2020 & $(1$-aminopyrrolidin-2-one) which undergo many reactions to prepare the other \\
Published: & derivatives. The prepared derivatives were determined by utilizing their FT-IR, \\
01.12 .2020 & 1H-NMR and some by Mass spectrum. These derivatives were evaluated \\
\hline Keywords: & biologically against (Staphylococcus aureus and E. coll). Some of these \\
Lactamization & derivatives exhibited good biological activity against one or both kind of bacteria \\
Pyrrolidine-2-one & while some exhibited no biological activity at all. \\
Biological activity & \\
\hline
\end{tabular}

DOI: $10.22401 /$ ANJS.23.4.02

${ }^{*}$ Corresponding author: 130139@uotechnology.edu.iq

\section{Introduction}

2-Pyrrolidinones are lactams of 5-membered ring with biological interest. Pyrrolidine-2-one is the simplest 2pyrrolidinones, see Figure 1; it is a colorless liquid that show miscibility with water and most organic solvents [1]. Pyrrolone referred to pyrrolidine-2-one in natural products [2]. When $\gamma$-butyrolactone (GBL) treated with $\mathrm{NH}_{3}$, pyrrolidine-2-one would produce and this process is used to prepare it industrially which is a straight process because reactants may not be pre-functionalized. However process needs harsh pressure or high temperature [3]. Pyrrolidine-2-one is an important component in several active natural products and pharmaceuticals [4]. Cotinine, an alkaloid found in tobacco considered to be biochemically important 2-pyrrolidinones which is the predominant metabolite of nicotine [5]. N-Substituted Pyrrolidine-2-one can be rapidly synthesized by condensation of GBL with primary amines that stand up to the temperatures range $\left(200-300{ }^{\circ} \mathrm{C}\right)$ which is necessary to eliminate water molecule and cyclize the hydroxyl butyl amide intermediate. A wide range of amines can be utilized [6]. Pyrrolidine-2-one could be the monomers of various synthetic polymers, like poly (1-vinylpyrrolidin-2one) derivatives [7].

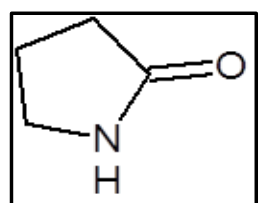

Figure 1. Structure of pyrrolidine-2-one.

\section{Experimental Parts \\ 2.1 Instruments}

Melting points were recorded and left uncorrected in open capillary tubes using Gallenkamp melting point apparatus. FT-IR spectrum was determined using a Perkin-Elmer 1600 series FT-IR spectrometer. ${ }^{1} \mathrm{H}-\mathrm{NMR}$ spectrum of synthesized derivatives was determined using $\mathrm{CDCL}_{3}$ as solvent and the other using DMSO with TMS as internal standard utilizing Varian-Mercury $300 \mathrm{MH}_{\mathrm{Z}}$ Spectrometer. Peak at $7.2 \mathrm{ppm}$ that belong to $\mathrm{CDCL}_{3}$ and the peaks at 2.5 and $3.3 \mathrm{ppm}$ that belong to DMSO and water impurities respectively may appear in these spectra. Mass spectra determined using (SHIMADZU model QP 1000EX using (SCI) mode

\subsection{Synthesis}

Synthesis of 1-aminopyrrolidin-2-one $\left(\mathbf{N}_{1}\right)$ [8]: $(0.01$ mol.) of hydrazine hydrate $(80 \%)$ was mixed with $(0.01$ mol.) of GBL and heated to $220{ }^{\circ} \mathrm{C}$ for $(24 \mathrm{hrs}$.) in an oil bath under reflux. Afterwards a white precipitate was obtained and washed with petroleum ether and acetone and then recrystallized from absolute $\mathrm{C}_{2} \mathrm{H}_{5} \mathrm{OH}$. Yield $(68 \%)$, color (white), m.p. $\left(85-87{ }^{\circ} \mathrm{C}\right)$, M.Wt. (100), FT-IR $v\left(\mathrm{~cm}^{-1}\right):(3294,3203)$ attribute to sym. and asym. Stretching vibration of $\left(-\mathrm{NH}_{2}\right),(2964,2877)$ attribute to (CH aliph.), (1703) attribute to stretching vibration of $(\mathrm{C}=\mathrm{O})$ of lactam ring, 1635 attribute to bending vibration of $(\mathrm{NH}),{ }^{1} \mathrm{H}-\mathrm{NMR}$ spectrum (ppm), (1.03) (m,2H,CH aliph.) far from carbonyl and nitrogen of lactam ring, (1.52) (t, 2H, CH aliph.) near nitrogen atom of lactam ring, (2.50) (t, $2 \mathrm{H}, \mathrm{CH}$ aliph.) near carbonyl group of lactam 


\section{Al-Nahrain Journal of Science}

ANJS, Vol.23 (4), December, 2020, pp. 5-12

ring, (2.16) (s, 2H, $\mathrm{NH}_{2}$ ), Mass, the molecular ion peak $(\mathrm{M}+, \mathrm{m} / \mathrm{z})=100$.

Synthesis of dimethyl (2-oxopyrrolidin-1-yl) carbonodithioimidoate $\left(\mathbf{N}_{2}\right)$ [9]: $(5 \mathrm{ml})$ of $20 \mathrm{M}-\mathrm{NaOH},(0.02$ mol.) of $\mathrm{CS}_{2}$ and $\left(0.01 \mathrm{~mol}\right.$.) of $\mathrm{CH}_{3} \mathrm{I}$ were added to stirred cold solution of $\left(0.01 \mathrm{~mol}\right.$.) of compound $\left(\mathrm{N}_{1}\right)$ in $(25 \mathrm{ml})$ DMF. The stirring was continued for (4 hrs.). The mixture was poured onto cold water and the obtained solid recrystallized from benzene. Yield (54\%), color (dark yellow), m.p. (108-110 $\left.{ }^{\circ} \mathrm{C}\right)$, M.Wt. (204), FT-IR $v\left(\mathrm{~cm}^{-1}\right)$ : (2862) belong to ( $\mathrm{CH}$ aliph.), (1678, 1600) belong to stretching vibration of $(\mathrm{C}=\mathrm{O})$ of lactam and of $(\mathrm{C}=\mathrm{N})$ respectively. ${ }^{1} \mathrm{H}-\mathrm{NMR}$ spectrum (ppm), (1.10) (m, 2H, $\mathrm{CH}_{2}$ aliph.), (1.55) (t, 4H, 2 $\mathrm{CH}_{2}$ aliph.), (2.50) (s, 6H, $2 \mathrm{CH}_{3}$ aliph.).

Synthesis of 2,6,7,8-tetrahydropyrrolo[1,2-b] [1,2,4,5] tetrazine-3(4H)-thione (N3) [10]: $(0.01$ mol.) of compound $\left(\mathrm{N}_{1}\right)$ was added to a solution of $(0.01 \mathrm{~mol}$.) $\mathrm{KOH}$ in $\mathrm{C}_{2} \mathrm{H}_{5} \mathrm{OH}$ at $\left(0{ }^{\circ} \mathrm{C}\right)$ then $\left(0.01 \mathrm{~mol}\right.$.) of $\mathrm{CS}_{2}$ was gradually add to this solution with stirring for an hour and then add (0.1 mol.) of $99 \%$ hydrazine and stirring continued for another hour with raising temperature to 45 $\left.{ }^{\circ} \mathrm{C}-55{ }^{\circ} \mathrm{C}\right)$. The obtained solid filtered and washed with water and recrystallized from $\mathrm{C}_{2} \mathrm{H}_{5} \mathrm{OH}$. Yield (70\%), color (white), m.p. (172-174 $\left.{ }^{\circ} \mathrm{C}\right)$, M.Wt. (156), FT-IR $v\left(\mathrm{~cm}^{-1}\right)$ : $(3549,3408)$ belong to stretching vibration of $(-\mathrm{NH})$ of six membered ring, $(2918,2852)$ belong to stretching vibration of ( $\mathrm{CH}$ aliph.), (1610) belong to stretching vibration of $(\mathrm{C}=\mathrm{N}),{ }^{1} \mathrm{H}-\mathrm{NMR}$ spectrum (ppm), (1.60) (m,2H, $\mathrm{CH}_{2}$ aliph.), (2.09) (t, $4 \mathrm{H}, 2 \mathrm{CH}_{2}$ aliph.) singlet at (8.42) due to $2(-\mathrm{NH})$ bonded to $(\mathrm{C}=\mathrm{S})$.

Synthesis of compound 2-chloro- $N$ (2-oxopyrrolidene-1yl) $\left(\mathbf{N}_{4}\right)$ [11]: (0.01 mol.) of $\mathrm{ClCH}_{2} \mathrm{COCl}$ was added drop wise to $(20 \mathrm{ml})$ of benzene $\left(\mathrm{C}_{6} \mathrm{H}_{6}\right)$ containing $(0.01 \mathrm{~mol}$.) of compound $\left(\mathrm{N}_{1}\right)$, the solution was refluxed for $(4 \mathrm{hrs}$.). Afterwards, the reaction mixture was cooled to room temperature and solvent evaporated under reduced pressure, the formed precipitate was filtered off and recrystallized from $\mathrm{C}_{2} \mathrm{H}_{5} \mathrm{OH}$, yield $(73 \%$ ), color (creamy white), m.p. (128-130 $\left.{ }^{\circ} \mathrm{C}\right)$, M.Wt. (176), FT-IR $v\left(\mathrm{~cm}^{-1}\right)$, (3344) attribute to stretching vibration of $(-\mathrm{NH}),(2931$, 2833) attribute to stretching vibration of ( $\mathrm{CH}$ aliph.), (1693) attribute to stretching vibration of $(\mathrm{C}=\mathrm{O})$ of lactam ring, (1678) attribute to vibration of $(\mathrm{C}=\mathrm{O})$ of amide group. ${ }^{1} \mathrm{H}-\mathrm{NMR}$ spectrum (ppm) (2.11) (m, 2H, $\mathrm{CH}_{2}$ aliph.), (2.65) (t, 2H, $\mathrm{CH}_{2}$ aliph.), (3.32) (t, 2H, $\mathrm{CH}_{2}$ aliph.), (4.44) (s, 2H, $\mathrm{CH}_{2}$ between $\mathrm{NHCO}$ and chlorine atom), (5.69) (s, 1H, NHCO).

Synthesis of 2-imino-3-(2-oxopyrrolidin-1-yl)-1, 3thiazolidin-4-one $\left(\mathbf{N}_{5}\right)$ [12]: Solution of $(0.01 \mathrm{~mol}$.) of compound $\left(\mathrm{N}_{1}\right)$ and $\left(0.01 \mathrm{~mol}\right.$.) of $\mathrm{NH}_{4} \mathrm{SCN}$ in $(25 \mathrm{ml})$ $\mathrm{C}_{2} \mathrm{H}_{5} \mathrm{OH}$ was refluxed for (15-16 hrs.). The solution was cooled and poured onto crushed ice with continuous stirring. The obtained solid washed with cold water, dried and recrystallized from $\mathrm{CH}_{3} \mathrm{OH}$. yield (83\%), color(light yellow), m.p. (332-334 $\left.{ }^{\circ} \mathrm{C}\right)$, M.Wt. (199), FT-IR $v\left(\mathrm{~cm}^{-1}\right)$,
(3346) belong to stretching vibration of $(-\mathrm{NH})$, (2926, 2854) belong to stretching vibration of ( $\mathrm{CH}$ aliph.), (1699, 1674) attribute to stretching vibration of two carbonyl groups $(\mathrm{C}=\mathrm{O})$ of lactam rings, (1575) belong to stretching vibration of $(\mathrm{C}=\mathrm{N}),{ }^{1} \mathrm{H}-\mathrm{NMR}$ spectrum (ppm) (1.62) (m, $2 \mathrm{H}, \mathrm{CH}_{2}$ aliph.), (2.14) (t, 2H, $\mathrm{CH}_{2}$ aliph.), (2.67) (t, $2 \mathrm{H}$, $\mathrm{CH}_{2}$ aliph.), (5.69) (s, 1H, $\mathrm{NH}$ ) and (3.40) (s, 2H, $\mathrm{CH}_{2}$ aliph.) next to carbonyl group of lactam ring containing sulfur atom.

Synthesis of 1-[(2-amino-1, 3-thiozol-4-yl) amino] pyrrolidin-2-one $\left(\mathbf{N}_{6}\right)$ [13]: A mixture of $(0.01 \mathrm{~mol}$.) of compound $\left(\mathrm{N}_{4}\right)$ with $\left(0.01 \mathrm{~mol}\right.$.) of $\mathrm{NH}_{2} \mathrm{CSNH}_{2}$ in $(20 \mathrm{ml})$ of absolute $\mathrm{C}_{2} \mathrm{H}_{5} \mathrm{OH}$ were refluxed for $(12 \mathrm{hrs}$.), afterwards the mixture was cooled and then poured onto ice /water mixture. The formed precipitate was filtered, washed with $2 \% \mathrm{NaHCO}_{3}$ solution and then with $\mathrm{H}_{2} \mathrm{O}$, and recrystallized from absolute $\mathrm{C}_{2} \mathrm{H}_{5} \mathrm{OH}$. Yield (63\%), color (yellowish white), m.p. (194-196 $\left.{ }^{\circ} \mathrm{C}\right), \mathrm{M} . \mathrm{Wt} .(198)$. FT-IR $v\left(\mathrm{~cm}^{-1}\right),(3396,3358)$ and $(3265)$ due to stretching vibration of $\left(-\mathrm{NH}_{2}\right)$ and $(-\mathrm{NH}),(1699)$ due to stretching vibration of $(\mathrm{C}=\mathrm{O})$ of lactam ring. Mass, the molecular ion peak $(\mathrm{M}+, \mathrm{m} / \mathrm{z})=198$.

General synthesis of compounds $\left(\mathbf{N}_{\mathbf{7}}-\mathbf{N}_{\mathbf{9}}\right)$ [14]: $(0.01$ mol.) of compound $\left(\mathrm{N}_{1}\right)$ with $(0.01 \mathrm{~mol}$.) of phthalic anhydride or maleic anhydride / (0.01 mol.) of compound $\left(\mathrm{N}_{6}\right)$ with $(0.01 \mathrm{~mol}$.$) of phthalic anhydride in (15 \mathrm{ml})$ of (gla. $\left.\mathrm{CH}_{3} \mathrm{COOH}\right)$ were refluxed for $(3 \mathrm{hrs}$.). Afterwards $(25 \mathrm{ml})$ of cold water has been added to the reaction mixture and the formed precipitate was dried and recrystallized from absolute $\mathrm{C}_{2} \mathrm{H}_{5} \mathrm{OH}$.

2-(2-oxopyrrolidin-1-yl)-1H-isoindole-1,3(2H)-dione

$\left(\mathbf{N}_{7}\right)$ : yield $(69 \%)$, color (white), m.p. $\left(310-312{ }^{\circ} \mathrm{C}\right)$, M.Wt.(230), FT-IR $v\left(\mathrm{~cm}^{-1}\right),(3034,3014)$ due to stretching vibration of ( $\mathrm{CH}$ arom.), (2953) due to stretching vibration of ( $\mathrm{CH}$ aliph.), (1739) belong to stretching vibration of two carbonyl groups of imide ring, (1718) belong to stretching vibration of $(\mathrm{C}=\mathrm{O})$ of lactam ring, (1600) belong to stretching vibration of ( $\mathrm{C}=\mathrm{C}$ arom.), ${ }^{1} \mathrm{H}-\mathrm{NMR}$ spectrum (ppm) (0.89) (m, 2H, $\mathrm{CH}_{2}$ aliph.), (1.27) (t, 2H, $\mathrm{CH}_{2}$ aliph.), (1.64) (t, $\left.\mathrm{CH}_{2}, 2 \mathrm{H}\right),(7.88-8.25)$ (m, aromatic protons).

1-(2-oxopyrrolidin-1-yl)-1H-pyrrol-2,5-dione $\left(\mathrm{N}_{8}\right)$ : yield (81\%), color (light yellow), m.p. (237-239 $\left.{ }^{\circ} \mathrm{C}\right)$, M.Wt. (180), FT-IR $v\left(\mathrm{~cm}^{-1}\right),(2937,2879)$ belong to stretching vibration of ( $\mathrm{CH}$ aliph.), (1739) belong to stretching vibration of two carbonyl groups $(\mathrm{C}=\mathrm{O})$ of imide ring, (1714) belong to stretching vibration of $(\mathrm{C}=\mathrm{O})$ of lactam ring, (1651) belong to stretching vibration of $(\mathrm{C}=\mathrm{C}$ arom.), ${ }^{1} \mathrm{H}-\mathrm{NMR}$ spectrum (ppm) (1.64) (m, 2H, $\mathrm{CH}_{2}$ aliph.), (2.14) (t, $4 \mathrm{H}, 2 \mathrm{CH}_{2}$ aliph.), (4.44) (d, 2 vinyl protons).

2-\{4-[(2-oxopyrrolidin-1-yl)amino]-1,3-thiazole-2-yl\}-1Hisoindole-1,3(2H)-dione $\quad\left(\mathbf{N}_{9}\right)$ : yield $(73 \%)$, color (creamy), m.p. (304-306 $\left.{ }^{\circ} \mathrm{C}\right)$, M.Wt. (328) FT-IR $v\left(\mathrm{~cm}^{-1}\right)$, (3263) due to stretching vibration of $(-\mathrm{NH}),(2993)$ due to (CH aliph.), (1716) due to stretching vibration of two carbonyl groups $(\mathrm{C}=\mathrm{O})$ of imide ring, (1662) due to 


\section{Al-Nahrain Journal of Science}

ANJS, Vol.23 (4), December, 2020, pp. 5-12

stretching vibration of $(\mathrm{C}=\mathrm{O})$ of lactam ring, (1539) due to stretching vibration of $(\mathrm{C}=\mathrm{N}),{ }^{1} \mathrm{H}-\mathrm{NMR}$ spectrum (ppm),(0.63) (m, 2H, $\mathrm{CH}_{2}$ aliph.), (1.24) (m, 4H, $\mathrm{CH}_{2}$ aliph.), (7.31-7.68) (m, aromatic protons and $1 \mathrm{H}(-\mathrm{NH})$ of thiazol ring).

General synthesis of compounds $\left(\mathbf{N}_{10}, \mathbf{N}_{11}\right)$ [15]: (0.01 mol.) of aromatic aldehyds (p-chloro benzaldehyde or $\mathrm{p}$ nitro benzaldehyde) was added to a solution of $(0.01 \mathrm{~mol}$.) of compound $\left(\mathrm{N}_{6}\right)$ in $(20 \mathrm{ml})$ absolute $\mathrm{C}_{2} \mathrm{H}_{5} \mathrm{OH}$ in presence of (4 drops) of glacial $\mathrm{CH}_{3} \mathrm{COOH}$. The mixture was refluxed for (3-6 hrs.). Afterwards, the mixture was cooled, filtered and the obtained solid recrystallized from $\mathrm{C}_{2} \mathrm{H}_{5} \mathrm{OH}$ to afford the wanted compounds.

1-[(2-\{[(Z)-(4-chlorophenyl) methylidene] amino\}-1, 3thiazol-4-yl) amino] pyrrolidin-2-one $\left(\mathbf{N}_{10}\right)$ : yield $(79 \%)$, color (yellow), m.p. (188-190 $\left.{ }^{\circ} \mathrm{C}\right)$, M.Wt. (317) FT-IR $v\left(\mathrm{~cm}^{-1}\right),(3033)$ due to stretching vibration of (CH arom.), (2953, 2852) due to stretching vibration of ( $\mathrm{CH}$ aliph.), (1683) due to stretching vibration of $(\mathrm{C}=\mathrm{O})$ of lactam ring, (1668) belong to stretching vibration of $(\mathrm{C}=\mathrm{N})$.

1-[(2-\{[(Z)-(4-nitrorophenyl) methylidene $]$ amino $\}-1,3-$ thiazol-4-yl) amino] pyrrolidin-2-one $\left(\mathrm{N}_{11}\right)$ : yield $(72 \%)$, color (yellow), m.p. (219-221 $\left.{ }^{\circ} \mathrm{C}\right)$, M.Wt. (331), FT-IR $v\left(\mathrm{~cm}^{-1}\right),(3043)$ due to stretching vibration of $(\mathrm{CH}$ arom.) (2922, 2852) due to stretching vibration of ( $\mathrm{CH}$ aliph.), (1693) due to stretching vibration of $(\mathrm{C}=\mathrm{O})$ of lactam ring, (1666) due to stretching vibration of $(\mathrm{C}=\mathrm{N}),(1572,1330)$ due to vibration of $\left(-\mathrm{NO}_{2}\right),{ }^{1} \mathrm{H}-\mathrm{NMR}$ spectrum (ppm) (0.85) (m, 2H, $\mathrm{CH}_{2}$ aliph.), (1.34) (t, 4H, 2 $\mathrm{CH}_{2}$ aliph.), (6.73), (7.71) (d, d, Para sub. Benzene), (7.49) (s, proton of thiazole ring), (7.52) (s.1H, NH), (8.75) (s, 1H, $(\mathrm{N}=\mathrm{CH}))$.

Synthesis of 1-naphthalen-1-yl-3-(2-oxopyrrolidin-1-yl) urea $\left(\mathbf{N}_{12}\right)$ [16]: (0.01 mol.) of naphthyl isocyanate was added to a solution of $\left(0.01\right.$ mol.) of compound $\left(\mathrm{N}_{1}\right)$ dissolved in $(20 \mathrm{ml}) \mathrm{DMF}$ and then refluxed for $(7 \mathrm{hrs}$.). A precipitate then formed immediately when $(20 \mathrm{ml})$ of diethyl ether was added to the solution, a mixture of ethanol: water (1:1) was used for recrystallization. Yield (80\%), color (light pink),m. p. (132-134 $\left.{ }^{\circ} \mathrm{C}\right)$, M.Wt. (269), FT-IR $v\left(\mathrm{~cm}^{-1}\right)$ : $(3282,3203)$ due to stretching vibration of tow $(\mathrm{NH})$ of $(\mathrm{NH}-\mathrm{C}=\mathrm{O}-\mathrm{NH}),(3037)$ due to stretching vibration of $(\mathrm{CH})$ aromatic, $(2955,2879)$ due to stretching vibration of $(\mathrm{CH})$ aliph., $(1701,1651)$ due to stretching vibration of $(\mathrm{C}=\mathrm{O})$ groups of lactam ring and $(\mathrm{NHC}=\mathrm{ONH})$ respectively, ${ }^{1} \mathrm{H}-\mathrm{NMR}$ spectrum (ppm), (0.87) (m, 2H, $\mathrm{CH}_{2}$ aliph.), 1.78 (t, 4H, 2 $\mathrm{CH}_{2}$ aliph.), 7.47$7.64(\mathrm{~m}$, aromatic protons and protons of (NHCONH)).

Synthesis of compound 1-(2-oxopyrrolidin-1-yl)-3phenylthiourea $\left(\mathbf{N}_{13}\right)$ [17]: to a solution of $(0.01 \mathrm{~mol}$.) of compound $\left(\mathrm{N}_{1}\right)$ in $(25 \mathrm{ml})$ of DMF, $(0.01 \mathrm{~mol}$.) of Phenyl isothiocyanate was added and refluxed for (10-12 hrs.). The solution was poured onto ice/water mixture. The obtained precipitate was filtered and recrystallized from $\mathrm{C}_{2} \mathrm{H}_{5} \mathrm{OH}: \mathrm{H}_{2} \mathrm{O}$ mixture (10:1), yield (68\%), color (light brown), m.p. (150-152 $\left.{ }^{\circ} \mathrm{C}\right)$, M.Wt. (235), FT-IR $v\left(\mathrm{~cm}^{-1}\right)$ : $(3371,3203)$ due to stretching vibration of $(\mathrm{NH})$ of
(NH-C=S-NH), (3043) due to stretching vibration of $(\mathrm{CH})$ aromatic, $(2965,2875)$ due to stretching vibration of $(\mathrm{CH})$ aliph., (1693) due to stretching vibration of $(\mathrm{C}=\mathrm{O})$ of lactam ring, (1338) due to stretching vibration of $(\mathrm{C}=\mathrm{S})$, ${ }^{1} \mathrm{H}-\mathrm{NMR}$ spectrum (ppm) (1.56) (m, 6H, $\mathrm{CH}_{2}$ aliph.), 7.88$8.23(\mathrm{~m}$, aromatic protons), $(8.49,9.16)(\mathrm{s}, 2 \mathrm{H}$, $\mathrm{NHC}=\mathrm{SNH})$.

General synthesis of compounds $\left(\mathbf{N}_{14}, \mathbf{N}_{15}\right)$ [18]: (0.01 mol.) of compound $\left(\mathrm{N}_{12}\right)$ or $\left(0.01 \mathrm{~mol}\right.$.) of compound $\left(\mathrm{N}_{13}\right)$ was mixed with $(0.01 \mathrm{~mol}$.) $\mathrm{N}, \mathrm{N}$-dimethyl benzaldehyde or P-nitro benzaldehyde respectively and then add (0.01 mol.) of ethyl acetoacetate and (0.005 mol.) LiBr. The mixture was heated in an oil bath with stirring at $90{ }^{\circ} \mathrm{C}$ for ( 3 hrs.). Afterwards, the mixture was cooled and then poured in ice/water mixture and the obtained solid was collected by filtration, washed with distilled $\mathrm{H}_{2} \mathrm{O}$, dried and recrystallized from $\mathrm{C}_{2} \mathrm{H}_{5} \mathrm{OH}$ to afford the pure product.

Methyl 4-(4-(dimethylamino)-1-(naphthalene-1-yl)-6methyl-2-oxo-3-(2-oxopyrrolidin-1-yl)1,2,3,4-tetrahydropyrimidine-5-carboxylate (N14): yield (61\%), color (bright yellow), m.p. (190-192 $\left.{ }^{\circ} \mathrm{C}\right)$, M.Wt. (498), FT-IR $v\left(\mathrm{~cm}^{-1}\right)$ : $(3059,3026)$ attribute to stretching vibration of (CH arom.), (2972,2879) attribute to stretching vibration of (CH aliph.), (1730,1716 and 1701) attribute to stretching vibrations of carbonyl groups of ester, lactam and urea moiety respectively, (1651) attribute to stretching vibration of $(\mathrm{C}=\mathrm{C})$ atoms., ${ }^{1} \mathrm{H}-\mathrm{NMR}$ spectrum $(\mathrm{ppm})$ (1.54) (m, 2H, $\mathrm{CH}_{2}$ aliph.), (2.01) (t, 2H, 2CH $\mathrm{CH}_{2}$ aliph.), (2.11) (t, $2 \mathrm{H}, 2 \mathrm{CH}_{2}$ aliph,), (2.72) (s, 6H, $\left.\mathrm{N}\left(\mathrm{CH}_{3}\right)_{2}\right),(2.85)(\mathrm{s}$, $\left.3 \mathrm{H}, \mathrm{CH}_{3}\right)$ attached to six membered ring, (4.52) $(\mathrm{s}, 5 \mathrm{H}$, $\mathrm{CH}_{2} \mathrm{CH}_{3}$ ) of ester group and (7.32-8.67) (m, aromatic proton).

Methyl 6-metyl-4-(4-nitrophenyl)-3-(2-oxopyrrolidine-1yl)-phenyl-2-thioxo-1,2,3,4-tetrahydropyrimidine-5carboxylate $\left(\mathbf{N}_{15}\right)$ : yield $(57 \%)$, color (dark yellow), m.p. $\left(118-120{ }^{\circ} \mathrm{C}\right)$, M.Wt. (389), FT-IR $v\left(\mathrm{~cm}^{-1}\right)$ : $(3072,3030)$ belong to vibration of ( $\mathrm{CH}$ arom.), $(2966,2831)$ belong to vibration of $(\mathrm{CH})$ aliph. (1728) (ester), (1708) (lactam), (1344) belong to vibration of $(\mathrm{C}=\mathrm{S}),{ }^{1} \mathrm{H}-\mathrm{NMR}$ spectrum (ppm) (0.84) (m, 2H, $\mathrm{CH}_{2}$ aliph.), (2.17) (t, 4H, 2 $\mathrm{CH}_{2}$ aliph.), (2.87) (s, 4H, $\mathrm{CH}$ benzylic, $\mathrm{CH}_{3}$ aliph. attached to six membered ring), (4.01) (m, $5 \mathrm{H}, \mathrm{CH}_{2} \mathrm{CH}_{3}$ of ester group) and (7.26-7.64) (m, aromatic protons).

\subsection{Biological activities [19]}

In vitro antimicrobial testing effects of pyrrolidine-2-one derivatives were estimated against two kinds of bacteria (Staphylococcus aureus and Escherichia Coli). Agar well diffusion was the method to determine the Antimicrobial activity. DMSO (Dimethyl sulfide) acted as a control and the test was set at $(1000,500) \mu \mathrm{g} / \mathrm{ml}$ concentration using (DMSO) as solvent. The bacteria were sub cultured in agar. The plates were incubated at $37{ }^{\circ} \mathrm{C}$ and checking after 24 hrs. 


\section{Al-Nahrain Journal of Science}

ANJS, Vol.23 (4), December, 2020, pp. 5-12

\section{Results and Discussion}

\subsection{Spectra}

The synthesis of compound $\left(\mathrm{N}_{1}\right)$ by lactamization of GBL with $\mathrm{NH}_{2} \mathrm{NH}_{2}(80 \%)$ was approved by FT-IR, ${ }^{1} \mathrm{H}-\mathrm{NMR}$ and Mass spectroscopy. FT-IR $\left(\mathrm{cm}^{-1}\right)$ spectrum of compound $\left(\mathrm{N}_{1}\right)$ exhibited disappearance of stretching vibration of $(\mathrm{C}=\mathrm{O})$ at $(1760)$ that was belong to $\mathrm{GBL}$ see Figure 2 and appearance of new band at (1703) which belong to carbonyl group $(\mathrm{C}=\mathrm{O})$ of lactam ring beside appearance of new bands at $(3294,3203)$ that attribute to symmetric and asymmetric stretching vibration of $\left(-\mathrm{NH}_{2}\right)$ group, see Figure 3. Spectra of ${ }^{1} \mathrm{H}-\mathrm{NMR}$ spectrum (ppm) for compound $\left(\mathrm{N}_{1}\right)$ exhibited multiplate at (1.03) attribute to $\left(2 \mathrm{H}, \mathrm{CH}_{2}\right.$ aliph.), triplet at (1.52) attribute to $\left(2 \mathrm{H}, \mathrm{CH}_{2}\right.$ aliph.), and a triplet at (2.50) due to $\left(2 \mathrm{H}, \mathrm{CH}_{2}\right.$ aliph.) next to carbonyl group of lactam ring, a singlet at (2.16) due to $\left(2 \mathrm{H}, \mathrm{NH}_{2}\right)$, see Figure 4. Mass spectra of compound $\left(\mathrm{N}_{1}\right)$ showed the molecular ion peak $(\mathrm{M}+, \mathrm{m} / \mathrm{z})=100$, which correspond to its molecular weight. Compound $\left(\mathrm{N}_{2}\right)$ was characterized using FT-IR $\left(\mathrm{cm}^{-1}\right)$ and ${ }^{1} \mathrm{H}-\mathrm{NMR}$ spectrum (ppm) techniques, the disappearance of $\left(-\mathrm{NH}_{2}\right)$ stretching vibration bands that belong to compound $\mathrm{N}_{1}$ and appearance of new bands at $(1600)$ that belong to $(\mathrm{C}=\mathrm{N})$ and appearance of band at (1678) due to lactam ring in FTIR spectrum of compound $\left(\mathrm{N}_{2}\right)$, see Figure 5, indicates its formation, the ${ }^{1} \mathrm{H}-\mathrm{NMR}$ spectrum (ppm) of this compound showed the following signals: -multiplate at (1.10) attribute to $\left(2 \mathrm{H}, \mathrm{CH}_{2}\right.$ aliph.), triplet at (1.55) attribute to $\left(4 \mathrm{H}, 2 \mathrm{CH}_{2}\right.$ aliph.), singlet at $(2.50)$ attribute to $\left(6 \mathrm{H}, 2 \mathrm{CH}_{3}\right.$ of $\left.-\mathrm{C}\left(\mathrm{SCH}_{3}\right)_{2}\right)$ and disappearance of $\left(-\mathrm{NH}_{2}\right)$ singlet peak that was at (2.16) in spectra of compound $\left(\mathrm{N}_{1}\right)$. Compound $\left(\mathrm{N}_{3}\right)$ was characterized using FT-IR $\left(\mathrm{cm}^{-1}\right),{ }^{1} \mathrm{H}-\mathrm{NMR}$ and Mass techniques, the disappearance of stretching vibration of $\left(-\mathrm{NH}_{2}\right)$ and $(\mathrm{C}=\mathrm{O})$ bands that belong to lactam ring of compound $\left(\mathrm{N}_{1}\right)$ and appearance of new bands at (3549, 3408 ) that belong to new $(-\mathrm{NH})$ bands of six membered and appearance of new bands at (1610) that belong to $(\mathrm{C}=\mathrm{N})$ in FT-IR spectrum, see Figure 6, indicate the formation of this compound. The ${ }^{1} \mathrm{H}-\mathrm{NMR}$ spectrum (ppm) of this compound has the following signals: -multiplate at (1.60) attribute to $\left(2 \mathrm{H}, \mathrm{CH}_{2}\right.$ aliph.), triplet at (2.09) attribute to $\left(4 \mathrm{H}, 2 \mathrm{CH}_{2}\right.$ aliph.), singlet at (8.42) attribute to $2(-\mathrm{NH})$ bonded to $(\mathrm{C}=\mathrm{S})$. Mass spectrum of the compound $\left(\mathrm{N}_{3}\right)$ showed the molecular ion peak $(\mathrm{M}+$, $\mathrm{m} / \mathrm{z})=156$ which corresponded to its molecular weight. The formation of compound $\left(\mathrm{N}_{4}\right)$ was confirmed by FT-IR and ${ }^{1} \mathrm{H}-\mathrm{NMR}$ spectroscopy, FT-IR $\left(\mathrm{cm}^{-1}\right)$ spectrum showed disappearance of stretching vibration of $\left(-\mathrm{NH}_{2}\right)$ of lactam ring of compound $\left(\mathrm{N}_{1}\right)$ and appearance of new band at (3344) attribute to stretching vibration of $(-\mathrm{NH})$ of amide group besides a band at (1693) and (1678) attribute to stretching vibration of $(\mathrm{C}=\mathrm{O})$ of lactam ring and amide group respectively and appearance of band at (812) attribute to $(\mathrm{C}-\mathrm{Cl}),{ }^{1} \mathrm{H}-\mathrm{NMR}$ spectrum (ppm) exhibited multiplate at (2.11) attribute to $\left(2 \mathrm{H}, \mathrm{CH}_{2}\right.$ aliph.), triplet at (2.65) attribute to $\left(2 \mathrm{H}, \mathrm{CH}_{2}\right.$ aliph.), triplet at (3.32) attribute to $\left(2 \mathrm{H}, \mathrm{CH}_{2}\right.$ aliph.),singlet at (4.44) attribute to $\left(2 \mathrm{H}, \mathrm{CH}_{2}-\mathrm{Cl}\right)$ and singlet at $(5.69)$ attribute to $(1 \mathrm{H}$, $-\mathrm{NHCO}$ ) which is a proof to formation of this compound. The formation of compound $\left(\mathrm{N}_{5}\right)$ was characterized using FT-IR and ${ }^{1} \mathrm{H}-\mathrm{NMR}$ techniques, the FT-IR $\left(\mathrm{cm}^{-1}\right)$ spectrum of compound $\left(\mathrm{N}_{5}\right)$ exhibited bands at (3346) attribute to stretching vibration of $(-\mathrm{NH})$ group, band at (1699) attribute to stretching vibration of $(\mathrm{C}=\mathrm{O})$ group of lactam ring, band at (1674) attribute to $(\mathrm{C}=\mathrm{O})$ stretching vibration absorptions of new lactam ring with sulfur atom. The ${ }^{1} \mathrm{H}-\mathrm{NMR}$ (ppm) spectrum of compound $\left(\mathrm{N}_{5}\right)$, see Figure 7, showed multiplate at (1.62) attribute to $\left(2 \mathrm{H}, \mathrm{CH}_{2}\right.$ aliph.), triplet at (2.14) attribute to $\left(2 \mathrm{H}, \mathrm{CH}_{2}\right.$ aliph.), triplet at (2.67) attribute to $\left(2 \mathrm{H}, \mathrm{CH}_{2}\right.$ aliph.), and singlet at (5.69) attribute to $(1 \mathrm{H}, \mathrm{NH})$ and singlet at $(3.40)$ attribute to $(2 \mathrm{H}$, $\mathrm{CH}_{2}$ aliph.) next to carbonyl group of lactam ring containing sulfur atom. Compounds $\left(\mathrm{N}_{6}\right)$ was confirmed by its FT-IR, and Mass spectroscopy, FT-IR $\left(\mathrm{cm}^{-1}\right)$ spectrum showed new bands at $(3396,3358)$ and (3265) belong to vibration of $(-\mathrm{NH})$ and $\left(-\mathrm{NH}-\mathrm{NH}_{2}\right)$, Mass spectra showed molecular ion peak $(\mathrm{M}+, \mathrm{m} / \mathrm{z})=198$, which correspond to its molecular weight. Compounds $\left(\mathrm{N}_{7}-\mathrm{N}_{9}\right)$ were characterized using FT-IR, ${ }^{1} \mathrm{H}-\mathrm{NMR}$ and some by Mass techniques, the disappearance of stretching vibration $\left(-\mathrm{NH}_{2}\right)$ bands at $(3294,3203)$ and $(3358,3265)$ that belong to compounds $\left(\mathrm{N}_{1}, \mathrm{~N}_{6}\right)$ respectively and appearance of new bands belong to new carbonyl groups $(\mathrm{C}=\mathrm{O})$ of imide rings in the range (1716-1739) in FT-IR spectrum of these compounds indicate their formation. Figure 8 showed the mass spectrum of the compound $\mathrm{N}_{7}$, the molecular ion peak $(\mathrm{M}+, \mathrm{m} / \mathrm{z})=230$ was corresponded to its molecular weight. The ${ }^{1} \mathrm{H}-\mathrm{NMR}$ spectrum (ppm) of compound $\mathrm{N}_{8}$ has the following signals: -multiplate at (1.64) attribute to $\left(2 \mathrm{H}, \mathrm{CH}_{2}\right.$ aliph.), triplet at (2.14) due $\left(4 \mathrm{H}, 2 \mathrm{CH}_{2}\right)$ aliphatic protons doublet at (4.44) attribute to (two vinyl protons).Compounds $\left(\mathrm{N}_{10}, \mathrm{~N}_{11}\right)$ were characterized using FT-IR and ${ }^{1} \mathrm{H}-\mathrm{NMR}$ techniques, the disappearance of the $\left(-\mathrm{NH}_{2}\right)$ stretching vibration bands that was at $(3358,3265)$ of compound $\left(\mathrm{N}_{6}\right)$ and appearance of new stretching vibration at (1668 and 1666) that belong to $(\mathrm{C}=\mathrm{N}$, imine group) indicates formation of Schiff bases. ${ }^{1} \mathrm{H}-\mathrm{NMR}$ spectrum (ppm) of compound $\left(\mathrm{N}_{11}\right)$ shows doublet at (6.73) and doublet at (7.71) attribute to Para sub. Benzene and singlet at $(8.75)$ attribute to $(\mathrm{N}=\mathrm{CH})$ group which indicate its formation, see Figure 9. The formation of compounds $\left(\mathrm{N}_{12}, \mathrm{~N}_{13}\right)$ has been proved by their FT-IR and ${ }^{1} \mathrm{H}-\mathrm{NMR}$, FT-IR $\left(\mathrm{cm}^{-1}\right)$ spectrum showed disappearance of sym. Vibration bands at $(3294,3203)$ that belong to stretching vibration of $\left(-\mathrm{NH}_{2}\right)$ group of compound $\left(\mathrm{N}_{1}\right)$ and appearance of new bands at (3282, $3203)$ and at $(3371,3203)$ that belong to vibration of $(-\mathrm{NH})$ in $(\mathrm{NHC}=\mathrm{ONH})$ and $(\mathrm{NH}-\mathrm{C}=\mathrm{S}-\mathrm{NH})$ moieties, respectively and appearance of band at (1651) and (1338) due to stretching vibration of $\mathrm{C}=\mathrm{O}$ and $\mathrm{C}=\mathrm{S}$ of $(\mathrm{NH}-\mathrm{C}=\mathrm{O}-\mathrm{NH}$ and $\mathrm{NH}-\mathrm{C}=\mathrm{S}-\mathrm{NH})$ in compound $\left(\mathrm{N}_{12}\right.$, $\mathrm{N}_{13}$ ), respectively, see Figure $10 .{ }^{1} \mathrm{H}-\mathrm{NMR}$ spectrum $(\mathrm{ppm})$ 


\section{Al-Nahrain Journal of Science}

ANJS, Vol.23 (4), December, 2020, pp. 5-12

of compound $\left(\mathrm{N}_{13}\right)$ has multiplate at (7.88-8.23) due to aromatic protons and two singlet peaks at (8.49) and at (9.16) due to protons of $(\mathrm{NH}-\mathrm{C}=\mathrm{S}-\mathrm{NH})$ which considered to be a proof for its formation.compounds $\left(\mathrm{N}_{14}, \mathrm{~N}_{15}\right)$ were characterized using FT-IR, ${ }^{1} \mathrm{H}-\mathrm{NMR}$ techniques, the disappearance of $(-\mathrm{NH})$ stretching vibration bands at $(3282,3203)$ and at $(3371,3203)$ of urea and thiourea moieties of compounds $\left(\mathrm{N}_{12}, \mathrm{~N}_{13}\right)$, respectively and appearance of new bands at $(1730,1728)$ that belong to new carbonyl groups $(\mathrm{C}=\mathrm{O})$ of ester attached to six membered ring in FT-IR spectrum of these compounds indicate their formation, the ${ }^{1} \mathrm{H}-\mathrm{NMR}$ spectrum (ppm) of compound $\left(\mathrm{N}_{15}\right)$, see Figure 11, show disappearance of singlet peaks at $(8.49,9.16)$ that belong to $(2 \mathrm{H}$, $\mathrm{NH}-\mathrm{C}=\mathrm{S}-\mathrm{NH})$ of compound $\left(\mathrm{N}_{13}\right)$ and appearance of singlet peaks at (2.87) and (4.01) due to $(4 \mathrm{H}, \mathrm{CH}$ benzylic, $\mathrm{CH}_{3}$ attached to six membered ring) and due to $(5 \mathrm{H}$, $\mathrm{CH}_{2} \mathrm{CH}_{3}$ of ester group) respectively, indicate its formation.

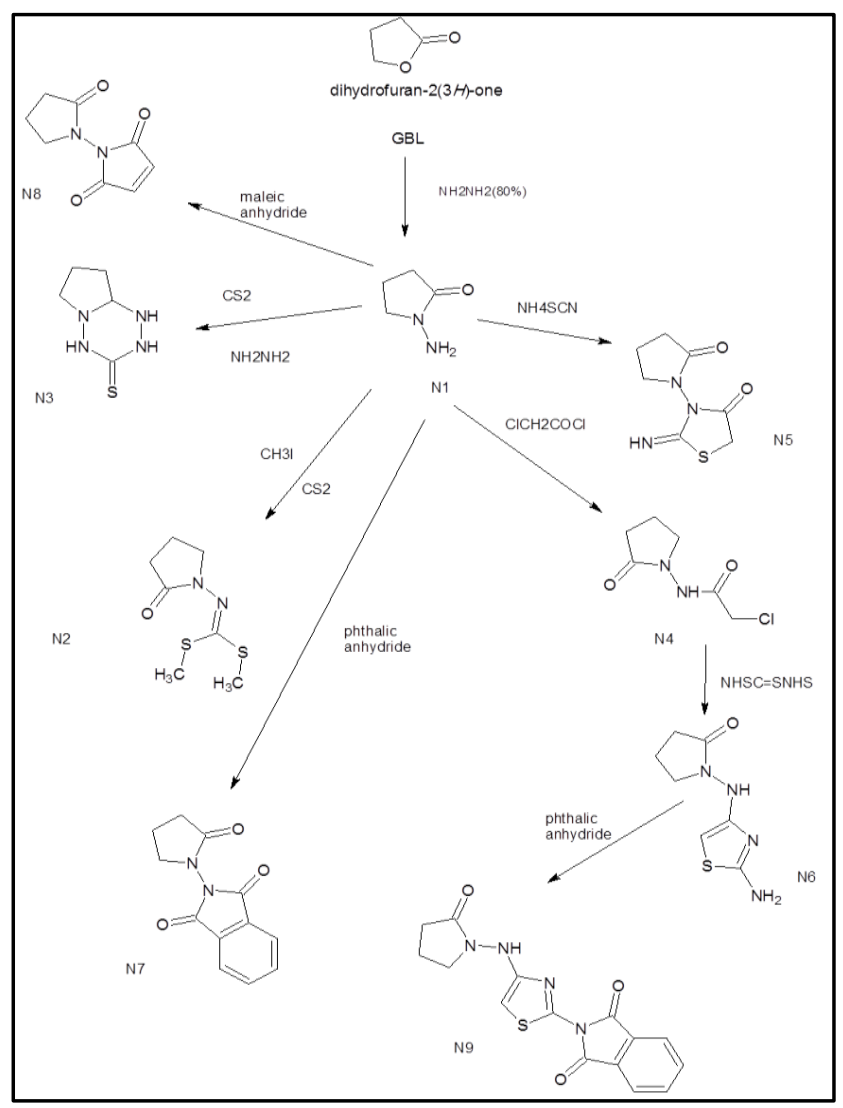

Scheme 1. Preparation steps for compounds $\mathrm{N}_{1}-\mathrm{N}_{9}$ compounds.

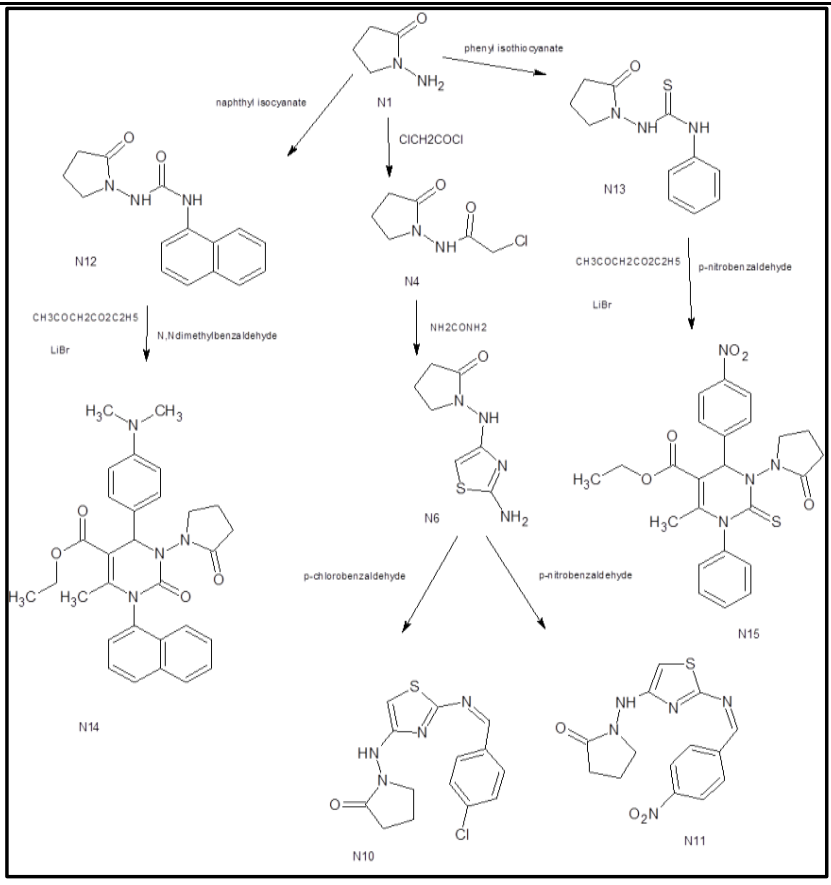

Scheme 2. Preparation steps for compounds $\mathrm{N}_{10}-\mathrm{N}_{15}$.

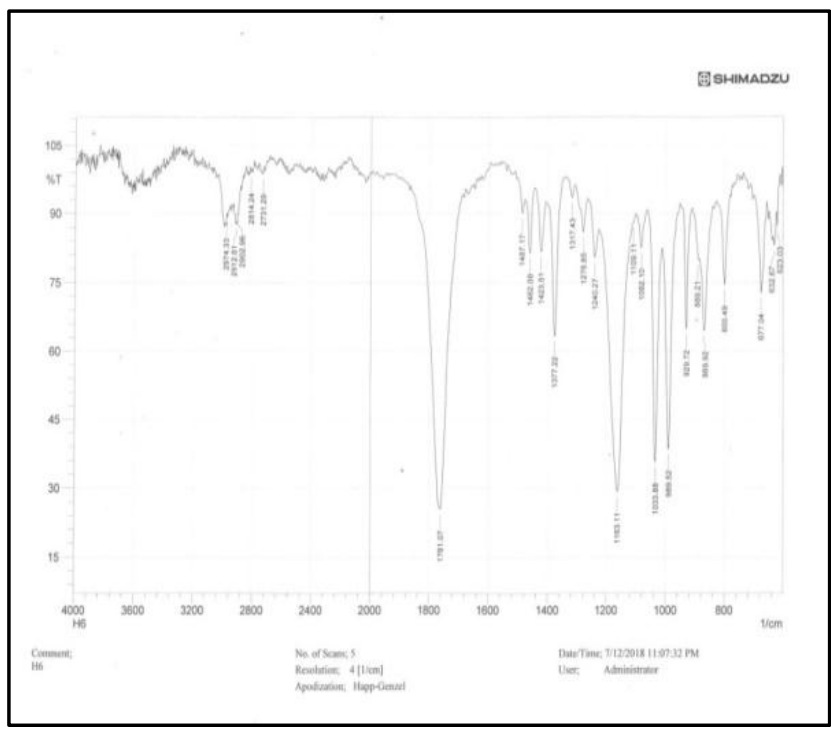

Figure 2. FT-IR spectrum of GBL. 


\section{Al-Nahrain Journal of Science}

ANJS, Vol.23 (4), December, 2020, pp. 5-12

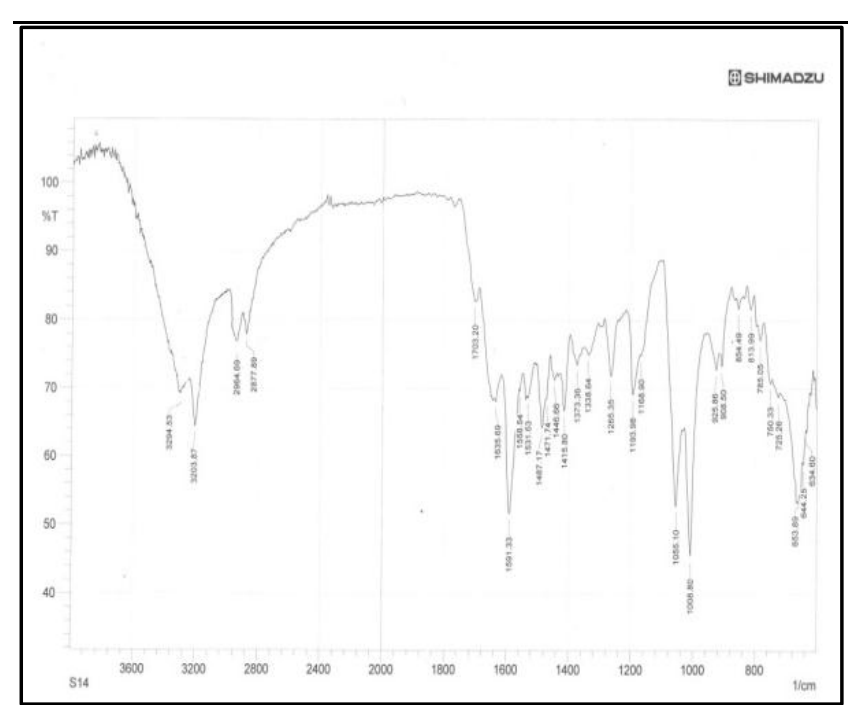

Figure 3. FT-IR spectrum of compound $\mathrm{N}_{1}$.

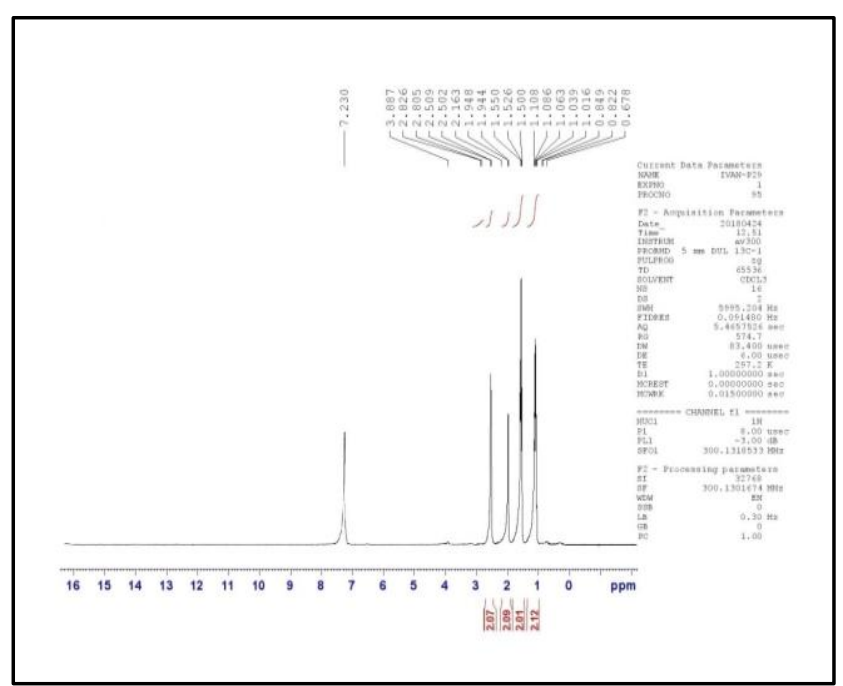

Figure 4. ${ }^{1} \mathrm{H}-\mathrm{NMR}$ spectrum of compound $\mathrm{N}_{1}$.

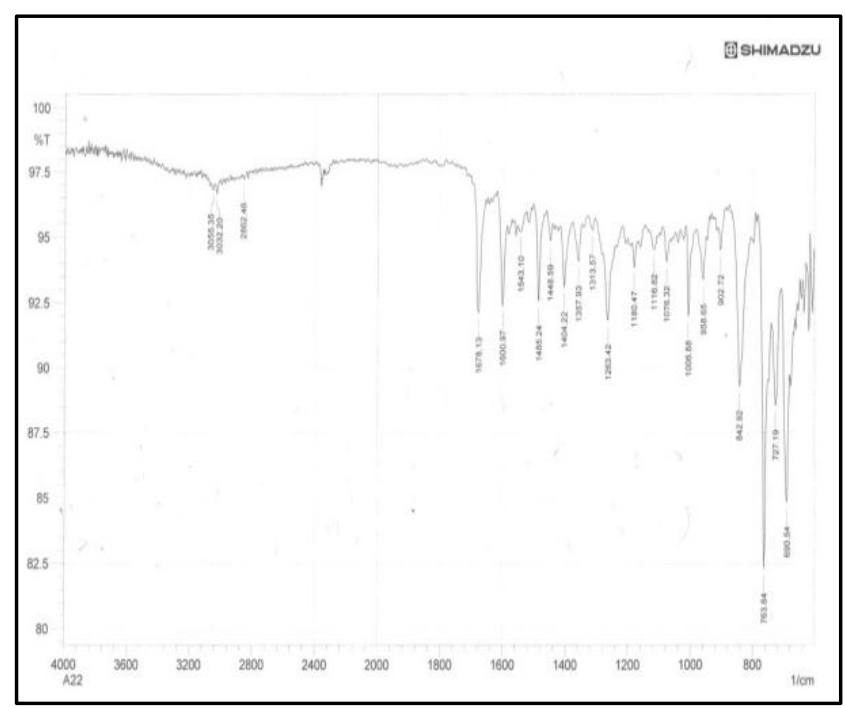

Figure 5. FT-IR spectrum of compound $\mathrm{N}_{2}$.

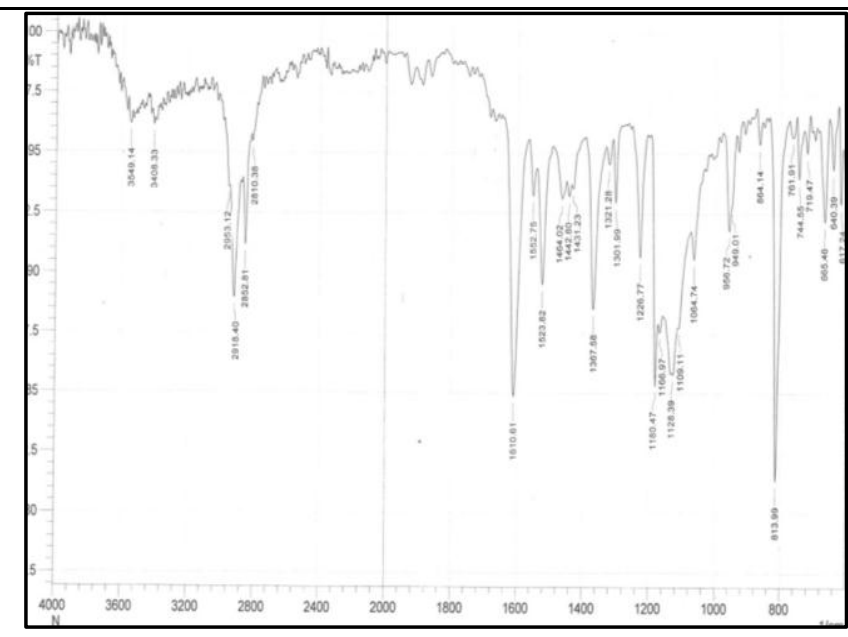

Figure 6. FT-IR spectrum of compound $\mathrm{N}_{3}$.

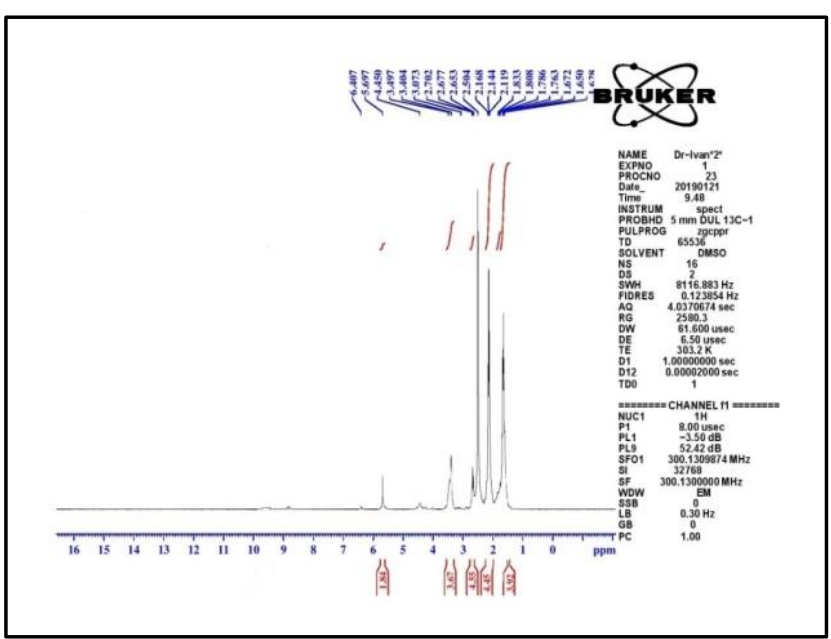

Figure 7. ${ }^{1} \mathrm{H}-\mathrm{NMR}$ spectrum of compound $\mathrm{N}_{5}$.

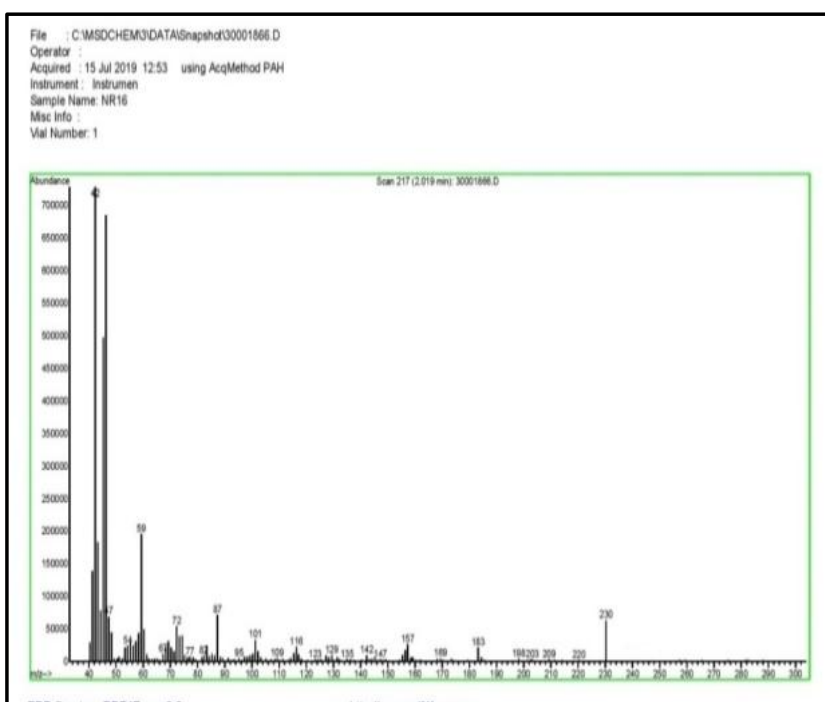

Figure 8. Mass spectrum of compound $\mathrm{N}_{7}$. 


\section{Al-Nahrain Journal of Science}

ANJS, Vol.23 (4), December, 2020, pp. 5-12

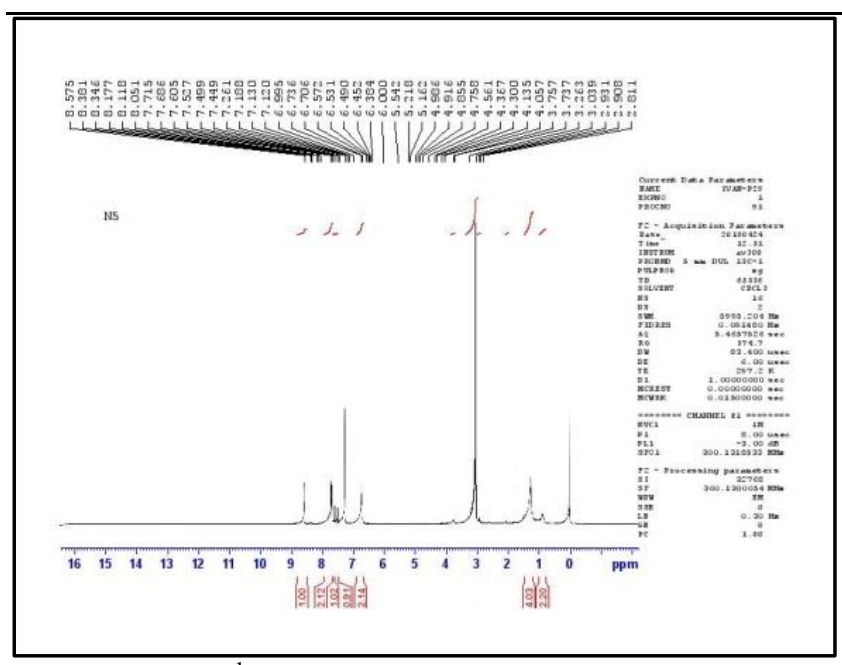

Figure 9. ${ }^{1} \mathrm{H}-\mathrm{NMR}$ spectrum of compound $\mathrm{N}_{11}$.

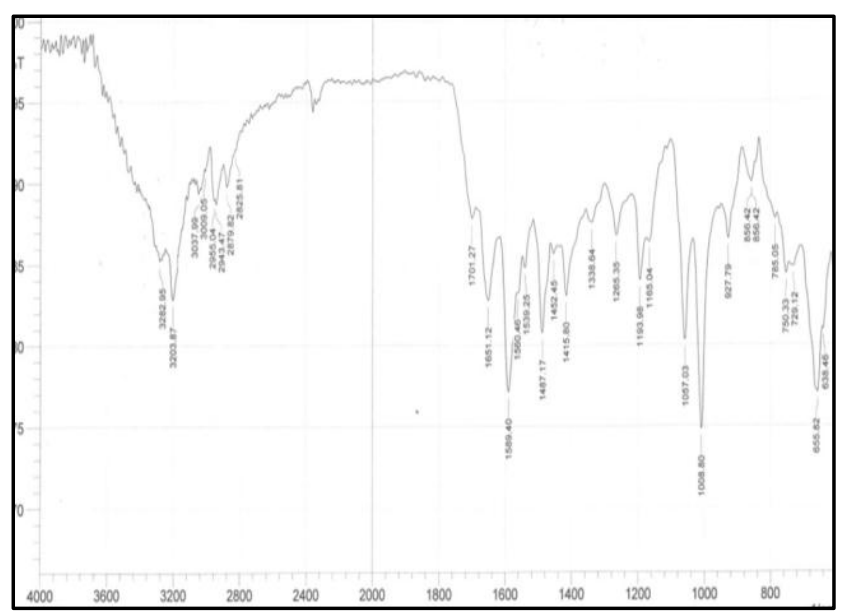

Figure 10. FT-IR spectrum of compound $\mathrm{N}_{12}$.

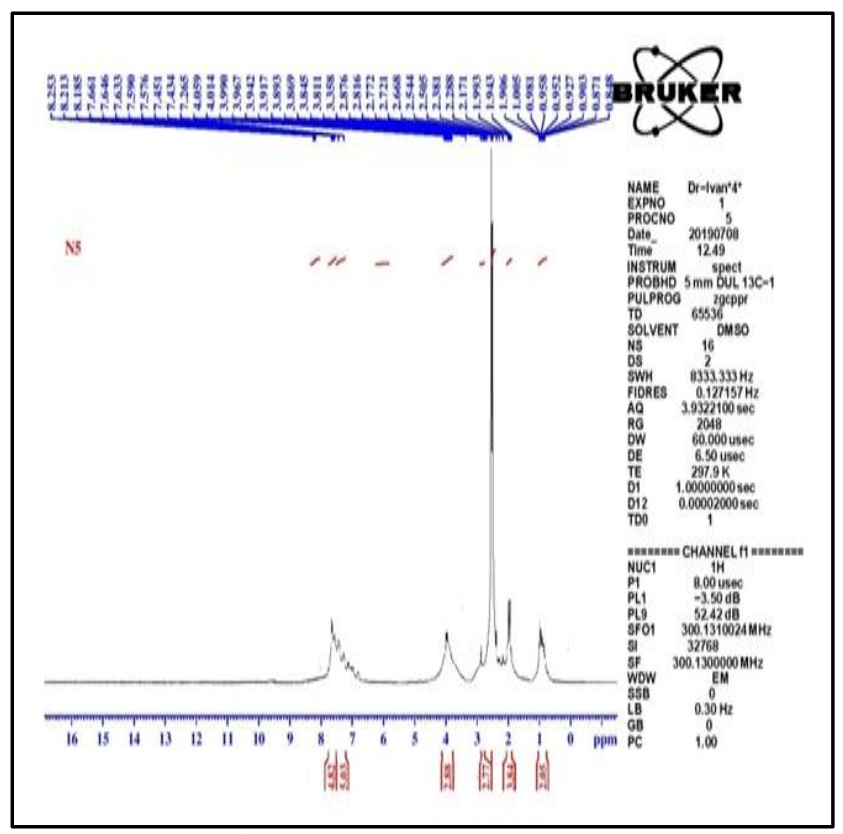

Figure 11. ${ }^{1} \mathrm{H}-\mathrm{NMR}$ spectrum of compound $\mathrm{N}_{15}$.

\subsection{Biological activity}

We see from Table 1 that Compounds $\mathrm{N}_{2}, \mathrm{~N}_{3}, \mathrm{~N}_{5}, \mathrm{~N}_{6}, \mathrm{~N}_{8}$, $\mathrm{N}_{11}, \mathrm{~N}_{12}$ and $\mathrm{N}_{13}$ showed biological activity for both kinds of bacteria (E. coli and St. aur.). Compound $\mathrm{N}_{4}$ and $\mathrm{N}_{10}$ show no biological activity at all. Compounds $\mathrm{N}_{7}, \mathrm{~N}_{14}$ show biological activity against E.coli. only. Compound $\mathrm{N}_{15}$ show biological activity against $S t$. aur. only.

Table 1. biological activity for prepared compounds toward E.coli and St.aur.

\begin{tabular}{|c|c|c|c|c|}
\hline & \multicolumn{2}{|c|}{$\begin{array}{c}\text { Escherichia Coli } \\
\text { Conc. }(\boldsymbol{\mu g} / \mathbf{m l}) \\
\text { Inhibition zone } \\
\text { diameter (mm) }\end{array}$} & \multicolumn{2}{c|}{$\begin{array}{c}\text { Staphylococcus } \\
\text { aureus } \\
\text { Conc. }(\boldsymbol{\mu g} \text { /ml) } \\
\text { Inhibition zone } \\
\text { diameter (mm) }\end{array}$} \\
\hline Comp. no. & 1000 & 500 & 1000 & 500 \\
\hline $\mathrm{N}_{1}$ & - & - & 12 & - \\
\hline $\mathrm{N}_{2}$ & 17 & - & 12 & - \\
\hline $\mathrm{N}_{3}$ & 23 & - & 17 & - \\
\hline $\mathrm{N}_{4}$ & - & - & - & - \\
\hline $\mathrm{N}_{5}$ & 16 & - & 15 & - \\
\hline $\mathrm{N}_{6}$ & 13 & - & 15 & - \\
\hline $\mathrm{N}_{7}$ & 7 & - & - & - \\
\hline $\mathrm{N}_{8}$ & 10 & - & 17 & - \\
\hline $\mathrm{N}_{9}$ & - & - & 18 & - \\
\hline $\mathrm{N}_{10}$ & - & - & - & - \\
\hline $\mathrm{N}_{11}$ & 20 & - & 11 & 11 \\
\hline $\mathrm{N}_{12}$ & 14 & - & 22 & - \\
\hline $\mathrm{N}_{13}$ & 20 & - & 18 & - \\
\hline $\mathrm{N}_{14}$ & 15 & - & - & - \\
\hline $\mathrm{N}_{15}$ & - & - & 11 & - \\
\hline & & & & \\
\hline
\end{tabular}

\section{Conclusion}

As conclusion, this work includes synthesis of new pyrrolidin-2-one derivatives by lactamization of GBL with amines derivatives with full characterization of the compounds by ${ }^{1} \mathrm{H}-\mathrm{NMR}$, FT-IR, and Mass spectroscopies. This indicates very good nucleophilic activities with using high temperature or pressure. It also has proved that these derivatives showed excellent biological activities against both E. coli and St. aur. bacteria.

\section{Acknowledgement}

Special thanks to department of materials engineering/ university of technology and Department of chemistry/college of science/Mustansiriyah University, Iraq for outstanding assistance to perform this research.

\section{References}

[1] Vogelsang, R.; Pinkos, R.; Mahn U.; "Ullmann's encyclopedia of industrial chemistry", John Wiley \& Sons, $1^{\text {st }}$ ed., West Sussex, England, 2011.

[2] Daniel, L. P.; Carsten B.; "The rhodium-catalyzed synthesis of pyrrolidinone-substituted (trialkylsilyloxy) acrylic esters”, RSC Adv., 3(16), 10318-10322, 2013. 


\section{Al-Nahrain Journal of Science}

ANJS, Vol.23 (4), December, 2020, pp. 5-12

[3] Ogliaruso, M. A.; Wolfe, J. F.; "In synthesis of lactones and lactams (1993)", John Wiley \& Sons, Inc., 1st ed., West Sussex, England, 2010.

[4] Ahankar, H.; Ramazani, A.; Ślepokura, K.; Lis, T.; Joo S. W.; "Synthesis of pyrrolidinone derivatives from aniline, an aldehyde and diethyl acetylenedicarboxylate in an ethanolic citric acid solution under ultrasound irradiation", J. Green Chem., 18(12), 3582-3593, 2016.

[5] Dwoskin, L. P.; Lihong, T.; Buxton, S. T.; Crooks, P. A.; "(S)-(-)-cotinine, the major brain metabolite of nicotine, stimulates nicotinic receptors to evoke $[3 \mathrm{H}]$ dopamine release from rat striatal slices in a calcium-dependent manner", J. of Pharm. and Exp. Therap., 288(3), 905-911, 1999.

[6] Robert, B. L.; "Pyrrolidone-based surfactants (a literature review)"; JAOCS, 72(7), 759-771, 1995.

[7] Haaf, F.; Sanner, A.; Straub, F.; "Polymers of Nvinylpyrrolidone: synthesis, characterization and uses", Polymer J., 17(1), 143-152, 1985.

[8] Michael, D.; Thi, T. H. N.; Jochen L.; "Investigations into the mechanism of lactamization of lactones yielding in a novel route to biologically active tryptamine derivatives", J. Tetrahedron, 60(21), 45674578, 2004.

[9] Aly, A. A.; El-Sayed, R.; "Synthesis and biological activity of new 1, 3, 4-thiadiazole derivatives", Chem. Pap., 60(1), 56-60, 2006.

[10] Mahdi, F. R.; "Synthesis of new compounds derived from $\mathrm{N}$-amino quinolone -2-one MSc. thesis, college of science/chemistry department/Mustansiriayh University, (2010).

[11] Mohamed, F. K.; "Synthesis, reactions and antimicrobial activity on some novel phthalazinones derivatives", Egypt. J. Chem. 53(5), 645-660, 2010.

[12] Navin, B. P.; Sarvil, D. P.; "Synthesis and in vitro antimicrobial studies of 4-thiazolidinone incorporated 1, 3, 4-oxadiazoles"; Chem. \& Bio. Interface; 2(3), 183-198, 2012.

[13] Karam, N. H.; Tomma J. H.; Al-Dujaili, A. H.; "Synthesis and characterization of heterocyclic compounds derived from 4-hydroxy and 4-amino acetophenone", Ibn Al-Haitham J. for Pure and Appl. Sci., 26(3), 296-312, 2013.

[14] Hasan, S. M.; Samir, A. H.; Majeed, I. Y.; "Synthesis and characterization of novel Schiff bases of imide moiety", Ibn Al-Haitham J. for Pure and Appl. Sci., 27(3), 407-420,2014.

[15] Abdul-Wahid, J. H.; Ayad, S. H.; Aveen, K. M.; "Synthesis characterization of some new heterocyclic compounds containing 1, 3-oxazepine ring", Kirkuk Univ. J./Sci. Stu. (KUJSS), 11(3), 237-247, 2016.

[16] Milan, C.; Mladen, T.; Frane, C., Elizabeta, S.; "Synthesis and antimicrobial activity of some derivatives of (7-hydroxy-2-oxo-2h-chromen-4-yl)acetic acid hydrazide", Molecules, 11(2), 134-147, 2006.
[17] Ahamed, L. S.; "Synthesis and characterization of new N-substituted quinoline-2-one derivatives and evaluation of their biological activity", Ph.D. thesis, chemistry dep., college of science, Mustansiriyah Univ., Iraq, 2016.

[18] Farhadi, A.; Takassi, M. A.; Hejazi, L.; "One-pot synthesis of 2-oxo-1,2,3,4-tetrahydropyrimidines using homogeneous catalyst under solvent-free conditions", Iran. Chem. Commun., 5(1), 35-41, 2017.

[19] Anesini, C.; Perez, C.; "Screening of plants used in argentine folk medicine for antimicrobial activity", J. Ethnopharmacology., 39(2), 119-128,1993 . 